\title{
Electrochemical Behaviour of Iron in Chlorinated Alkaline Media. The Effect of Slurries from Granite Processing
}

\author{
Carmen M. Abreu, Alba Covelo, Belén Díaz, Lorena Freire, X. Ramón Nóvoa* and M. Consuelo Pérez
}

\author{
Universidade de Vigo, E. T. S. E. I., Rúa Maxwell, 9, Campus Universitário 36310 Vigo, Spain
}

\begin{abstract}
O Porriño é uma zona bem conhecida de pedreiras do sudoeste de Galiza, Espanha. Nas operações de processamento do granito são geradas $3 \times 10^{5}$ ton ano ${ }^{-1}$ de pó nesta área, com consequências graves para o meio ambiente. Este pó resultante comprovou ser um aditivo efíciente do concreto de alta resistência com melhoramento efetivo das suas propriedades mecânicas. Nenhum trabalho foi publicado acerca do efeito desta mistura na passivação de reforços de aço. O objetivo deste trabalho é analisar o comportamento electroquímico dos eletrodos de aço e de ferro em soluções alcalinas resultantes desta lama. O crescimento e evolução das camadas de passivação formadas nos eletrodos testados foram estudados por Voltametria Cíclica e Espectroscopia de Impedância Electroquímica. Foram usadas técnicas de Difração de raios-X e Microscopia de Varrimento por Elétrons para a caracterização morfológica e química dos filmes de passivação gerados. O efeito da presença de íons cloreto também foi considerado.

Porriño is a well known zone of quarry and stone working of the SW of Galicia, Spain. In granite's working processes $3 \times 10^{5}$ ton year ${ }^{-1}$ of granite powder are generated in this area, causing an important environmental problem. This dust has proved to be an efficient addition to high-strength concrete to improve mechanical properties. Nevertheless, no works have been published concerning the effect of this admixture in the passivation of steel reinforcements. The objective of the present work is to analyze the electrochemical behaviour of iron and carbon steel electrodes in alkaline solutions resulting from these slurries. The growth and evolution of the passive layers formed on the tested electrodes are studied by Cyclic Voltammetry and Electrochemical Impedance Spectroscopy. Scanning Electron Microscopy and X-ray powder Diffraction have been used for the morphological and chemical characterisation of the generated passive films. The effect of the presence of $\mathrm{Cl}^{-}$ions is also considered.
\end{abstract}

Keywords: granite slurry, corrosion inhibitors, CV, EIS

\section{Introduction}

Spain is one of the three major ornamental rock producers and the first European granite producer. $60 \%$ of the Spanish production is concentrated in the Porriño district (NW of Spain) with $3 \times 10^{5}$ ton year-1 ${ }^{-1}$ The granite cutting residues are originated from the sawing process of rock blocks into plates. In this process, $20 \%$ to $30 \%$ $(\mathrm{m} / \mathrm{m})$ of mineral is transformed into dust which mixed with water, shot-blasting particles, lubricants, tensioactives and lime form the so-called granite cutting slurries, GCS. The solid and liquid phases are separated by density difference: the solid fraction remains into a tank while the liquid fraction is recycled at the beginning of process.

*e-mail: rnovoa@uvigo.es
The particles present in the solid phase are classified in two sizes: the greater fraction, used as aggregates for concrete, and the finer fraction which nowadays is useless, remains as waste accumulated in landfills. The environmental problem generated urges to find a solution acceptable from the economical and ecological points of view.

The recycling of industrial wastes in concrete manufacturing is a matter of increasing interest worldwide. Indeed, concrete technology can use great amounts of industrial residues as secondary raw materials. For instance, blended cements are normally produced by adding different quantities of coal fly ash, silica fume or ground granulated blast furnace slag to Portland cement clinker. These mineral additions, that have been initially simply used as recycled wastes, turned out to be beneficial with regard to the properties of concrete, especially in relation to its resistance to 
aggressive agents. ${ }^{1,2}$ Preliminary works suggested the possibility of using GCS as an additive in concrete structures, concluding that small additions of these slurries improved the mechanical resistance of concrete. ${ }^{3}$ However, the possible effects that granite slurry's additions can have in the passive layer of rebars must be studied prior to the use of GCS as cement additives.

The present paper is aimed to analyse the possible use of Granite Cutting Slurries as additive in reinforcing concrete structures, evaluating the GCS addition effect when chloride ions are present. The study is developed in two parts: A first one where the chemical and morphological properties of GCS are analysed, and a second one focused on the electrochemical behaviour of iron in alkaline solution containing GCS powder and chloride ions.

\section{Experimental}

\section{Characterization of GCS}

Granite Cutting sludge samples were obtained in Porriño (Pontevedra, Spain). The chemical characterization was done by chemical analysis of cations, X-Ray diffraction and titrations with $\mathrm{HCl} 0.1 \mathrm{~mol} \mathrm{~L}^{-1}$.

\section{Electrochemical tests}

Granite Cutting suspensions were prepared by adding $0.2 \mathrm{~g}$ of slurry to $150 \mathrm{~mL}$ of $\mathrm{NaOH} 0.1 \mathrm{~mol} \mathrm{~L}^{-1}$ solution. The electrochemical behaviour of iron in this suspension was compared with that of a reference without added GCS. Moreover, alkaline suspensions were used with two chloride concentrations: $0.2 \mathrm{~mol}$ $\mathrm{L}^{-1}$ and $0.5 \mathrm{~mol} \mathrm{~L}^{-1}$.

Electrochemical experiments were performed in a convectional three-electrode cell, where the tested material was corrugated carbon steel having $0.54 \mathrm{~cm}^{2}$ exposed area. The reference electrode was $\mathrm{Hg} / \mathrm{HgO}$ $0.1 \mathrm{~mol} \mathrm{~L}^{-1} \mathrm{KOH}$ and the counter electrode, a Pt mesh. When chloride ions were added to the solutions, a saturated calomel electrode (SCE) was employed as reference electrode. Before each experiment, the working electrode surface was freshly polished and rinsed with distilled water. All electrochemical tests were performed at room temperature and open to the air, using an AUTOLAB 30 Potentiostat (from EcoChemie). Two different electrochemical techniques were employed: Cyclic Voltammetry and Electrochemical Impedance Spectroscopy.
The scanned potential region for Cyclic Voltammetry tests was from hydrogen evolution $(-1.4 \mathrm{~V} v s$. SCE) to oxygen evolution $\left(+0.6 \mathrm{~V} v s\right.$. SCE) reactions at $1 \mathrm{mV} \mathrm{s}^{-1}$ scan rate, which allows relaxation of the redox process that take place in the passive layer. ${ }^{4}$

EIS tests were conducted at different immersion times (1, 2, 4 and 8 days). They were carried out at the corresponding Open Circuit Potential (OCP). The scanned frequencies interval was from $10 \mathrm{kHz}$ to $1 \mathrm{mHz}$. Similar experiments were carried out in solutions contaminated with chloride ions.

\section{Results and Discussion}

\section{Characterisation of the GCS}

X-ray Diffraction analysis shows the existence of different crystallographic forms. Figure 1 corresponds to the obtained diffraction spectrum Quartz $\left(\mathrm{SiO}_{2}\right)$, Biotite $\left(\mathrm{K}^{+}\left(\mathrm{Mg}^{2+}, \mathrm{Fe}^{2+}\right)\left(\mathrm{Al}^{3+}, \mathrm{Fe}^{3+}\right) \mathrm{Si}_{3} \mathrm{O}_{10}\left(\mathrm{OH}^{-}, \mathrm{F}^{-}\right)_{2}\right)$, Albite $\left(\mathrm{NaAlSi}_{3} \mathrm{O}_{8}\right.$ or $\left.\mathrm{CaAl}_{2} \mathrm{Si}_{2} \mathrm{O}_{8}\right)$ and an iron oxide, maghemite $\left(\mathrm{Fe}_{2} \mathrm{O}_{3}\right)$ can be identified. All those compounds are typical for granite rocks, and are considered to be alkaline in nature; this characteristic, chemical compounds in crystalline form, is typical of chemically stable compounds, therefore having low pozzolanic activity.

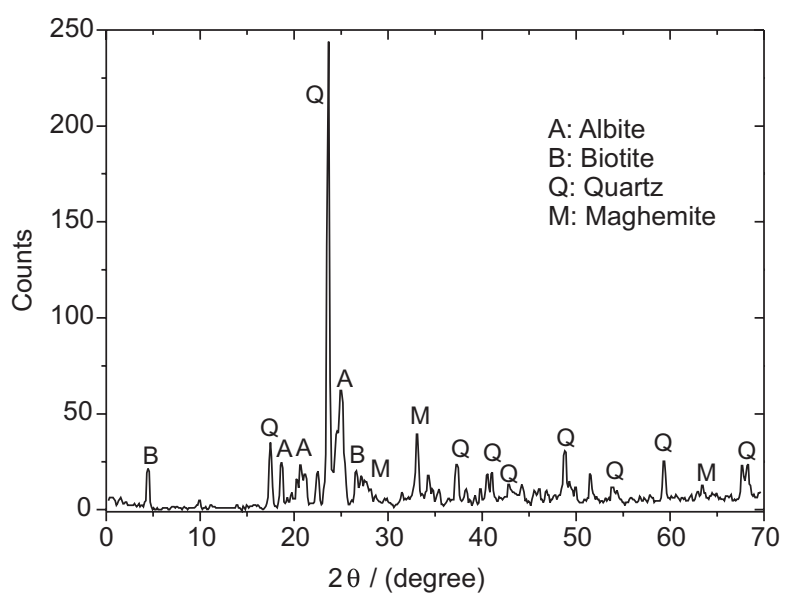

Figure 1. X-ray diffraction analysis of Granite Cutting Slurries showing the identified species present. X-axis corresponds to Bragg's angle $2 \theta$.

The elemental analysis performed on granite slurries allows obtaining the quantitative results that, given as upper oxides, are summarised in Table 1.

It is verified that, from the chemical point of view, the residue is composed mainly of $\mathrm{SiO}_{2}, \mathrm{Al}_{2} \mathrm{O}_{3}$ and $\mathrm{Fe}_{2} \mathrm{O}_{3}$ that corresponds to nearly $86 \%$. The high percentages of $\mathrm{SiO}_{2}$ and $\mathrm{Al}_{2} \mathrm{O}_{3}$ obtained are typical of igneous granitic rocks. 
Table 1. Chemical composition of the granite slurries

\begin{tabular}{lcccccccccccc}
\hline $\begin{array}{l}\text { Compounds } \\
\%(\mathrm{~m} / \mathrm{m})\end{array}$ & $\mathrm{SiO}_{2}$ & $\mathrm{Al}_{2} \mathrm{O}_{3}$ & $\mathrm{Fe}_{2} \mathrm{O}_{3}$ & $\mathrm{CaO}$ & $\mathrm{K}_{2} \mathrm{O}$ & $\mathrm{Na}_{2} \mathrm{O}$ & $\mathrm{MgO}$ & $\mathrm{TiO}_{2}$ & $\mathrm{P}_{2} \mathrm{O}_{5}$ & $\mathrm{SO}_{3}$ & $\mathrm{MnO}_{2}$ \\
05.840 & 13.0 & 7.118 & 5.540 & 3.470 & 3.140 & 0.871 & 0.332 & 0.280 & 0.089 & 0.089 \\
\hline Compounds & $\mathrm{Cl}$ & $\mathrm{BaO}$ & $\mathrm{SrO}$ & $\mathrm{ZrO}_{2}$ & $\mathrm{Cr}_{2} \mathrm{O}_{3}$ & $\mathrm{CuO}$ & $\mathrm{NiO}$ & $\mathrm{ZnO}$ & $\mathrm{N}$ & $\mathrm{C}$ & $\mathrm{H}$ \\
$\%(\mathrm{~m} / \mathrm{m})$ & 0.070 & 0.057 & 0.027 & 0.021 & 0.016 & 0.009 & 0.008 & 0.006 & 0.005 & 0.73 & 1.12 \\
\hline
\end{tabular}

The presence of $\mathrm{Fe}_{2} \mathrm{O}_{3}$ and $\mathrm{CaO}$ is probably related to foreign additions, like the addition of steel shot and lime as abrasive in the process of rock cutting /sawing.

In order to homogenize and mix slurries powder, a planetary ball mill was employed. Before milling, the particles size was 1 to $30 \mu \mathrm{m}$ and, after milling during $45 \mathrm{~min}$, the size was diminished to 1-5 $\mu \mathrm{m}$. These results are coincident with the bibliography where the size of particles was estimated by laser granulometry, obtaining $3.92 \mu \mathrm{m}$ average diameter after $80 \mathrm{~min}$ milling. ${ }^{5}$

In Figure 2 a SEM micrograph of these particles after the milling process is presented. It can be observed that particles are irregular in shape and size, with about $3 \mu \mathrm{m}$ average size. SEM-EDX analyses of a GCS powder sample show that chemical composition is particle size dependent. The smallest particles $(<1 \mu)$ are spherical and Si rich. The remaining particle sizes are irregular shape and rich in $\mathrm{Fe}, \mathrm{Ca}$ and $\mathrm{Al}$.

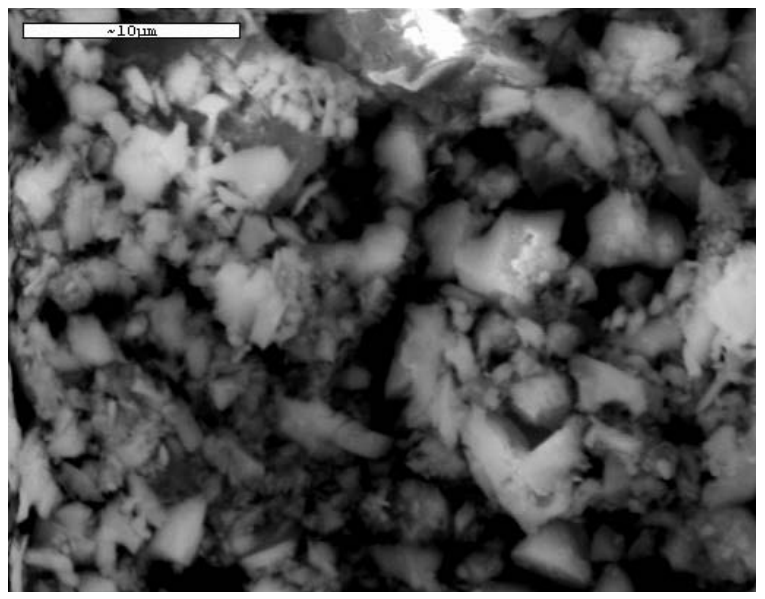

Figure 2. SEM micrograph obtained on a sample of GCS after $45 \mathrm{~min}$ milling.

Figure 3 presents the titration curve in alkaline media of a GCS suspension (with $2 \mathrm{~g} \mathrm{~L}^{-1}$ in $100 \mathrm{~mL}$ of $\mathrm{NaOH}$ $0.1 \mathrm{~mol} \mathrm{~L}^{-1}$ ) having as a reference a $\mathrm{NaOH} 0.1 \mathrm{~mol} \mathrm{~L}^{-1}$ solution.

The initial $\mathrm{pH}$ value (about 13) is similar for both solutions. Nevertheless, it can be seen that the GCS suspension needs $2 \mathrm{mmol} \mathrm{HCl}$ more than $\mathrm{NaOH}$ solution to neutralise. Thus, GCS show some "buffering power", similar to that found in red muds. ${ }^{6}$

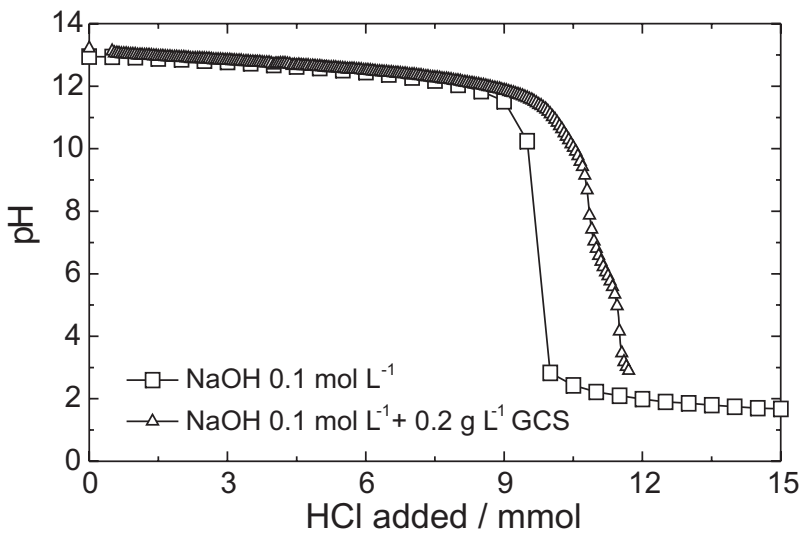

Figure 3. Tritation curve corresponding to $100 \mathrm{~mL}$ of $\mathrm{NaOH} 0.1 \mathrm{~mol} \mathrm{~L}^{-1}$ suspension containing $2 \mathrm{~g} \mathrm{~L}^{-1}$ of GCS and $\mathrm{NaOH} 0.1 \mathrm{~mol} \mathrm{~L}^{-1}$.

\section{Electrochemical behaviour of iron in alkaline solutions containing GCS}

\section{Solutions without chloride ions}

Carbon steel behaviour in alkaline solutions with GCS was analysed by Cyclic Voltammetry and Electrochemical Impedance Spectroscopy. These data were compared with those obtained for an iron electrode in $0.1 \mathrm{~mol} \mathrm{~L}^{-1} \mathrm{NaOH}$ solution.

Oxide films were grown by cyclic voltammetry (seven cycles) on carbon steel electrodes in the different solutions $\left(\mathrm{NaOH} 0.1 \mathrm{~mol} \mathrm{~L}^{-1}\right.$ without additives and with $2 \mathrm{~g} \mathrm{~L}^{-1}$ GCS). The voltammograms corresponding to the last cycle are depicted in Figure 4. Both forward scans show the activity peak at $-0.9 \mathrm{~V}$ vs. SCE, typical of magnetite

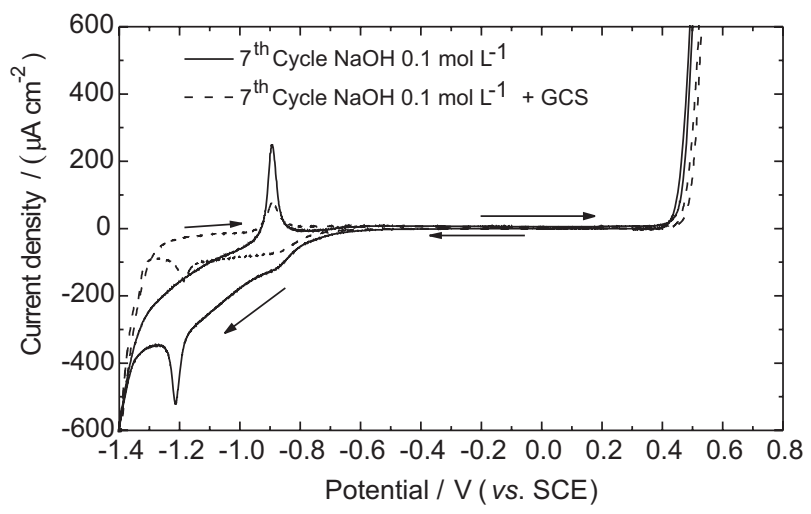

Figure 4. Comparison of the seventh cycles of carbon steel in $\mathrm{NaOH}$ $0.1 \mathrm{~mol} \mathrm{~L}^{-1}$, without and with $2 \mathrm{~g} \mathrm{~L}^{-1} \mathrm{GCS}$ added. 
formation, observed for iron electrode in alkaline media. ${ }^{7}$ Nevertheless, in presence of GCS both the peak current and current in the cathodic domain are lower. Moreover, the potential of oxygen evolution is shifted anodically. Those effects can be attributed to blockage of the carbon steel surface due to GCS.

Electrochemical Impedance Spectroscopy, EIS, was used in order to obtain additional information on the electrode processes involved. Figure 5 depicts the typical Bode impedance spectra obtained at 4 and 8 days immersion. The impedance spectra were recorded at the corresponding OCP values, which vary between $-200 \mathrm{mV}$ and $-100 \mathrm{mV}$ up to 8 days immersion time.

All plots reveal the presence of two time constants that can be attributed to the double layer capacitancecharge transfer resistance and the redox processes developing in the passive layer. ${ }^{8}$ Thus, the impedance can be modelled using equation 1 where $R_{e}$ represents the high frequency (electrolyte) resistance; $\mathrm{R}_{1}$ and $\mathrm{C}_{1}$ correspond to the double layer capacitance and charge transfer resistance; and the $\mathrm{R}_{2} \mathrm{C}_{2}$ time constant is associated to the redox processes developing in the passive layer. Good agreement is found between this model and the experimental data as illustrated in Figure $5 \mathrm{~A}$. The best fitting parameters for the data depicted in Figure 5 are given in Table 2.

$$
Z(\omega)=R_{e}+\frac{R_{1}}{\left(j \omega R_{1} C_{1}\right)^{\alpha_{1}}+1 /\left(1+\left(Z_{2}(\omega) / R_{1}\right)\right)} ; Z_{2}(\omega)=\frac{R_{2}}{1+\left(j \omega R_{2} C_{2}\right)^{\alpha_{2}}}
$$

It can be seen in Figure 5 that the overall impedance is higher for the solution containing GCS. Moreover, the high frequency resistance (see Re parameter in Table 2) is also higher for this solution. Variations in Re have been related to changes in the dielectric properties of passive films. ${ }^{9,10}$ In the present case, GCS could induce either the formation of an adsorbed layer which blocks the electrode surface, or a chemical modification of the passive layer, with similar result.

Table 2 shows also that double layer capacitance is smaller for the solution containing GCS. If the hypothesis of adsorbed layer applies, the result will be $\mathrm{C}_{1}$ decreasing
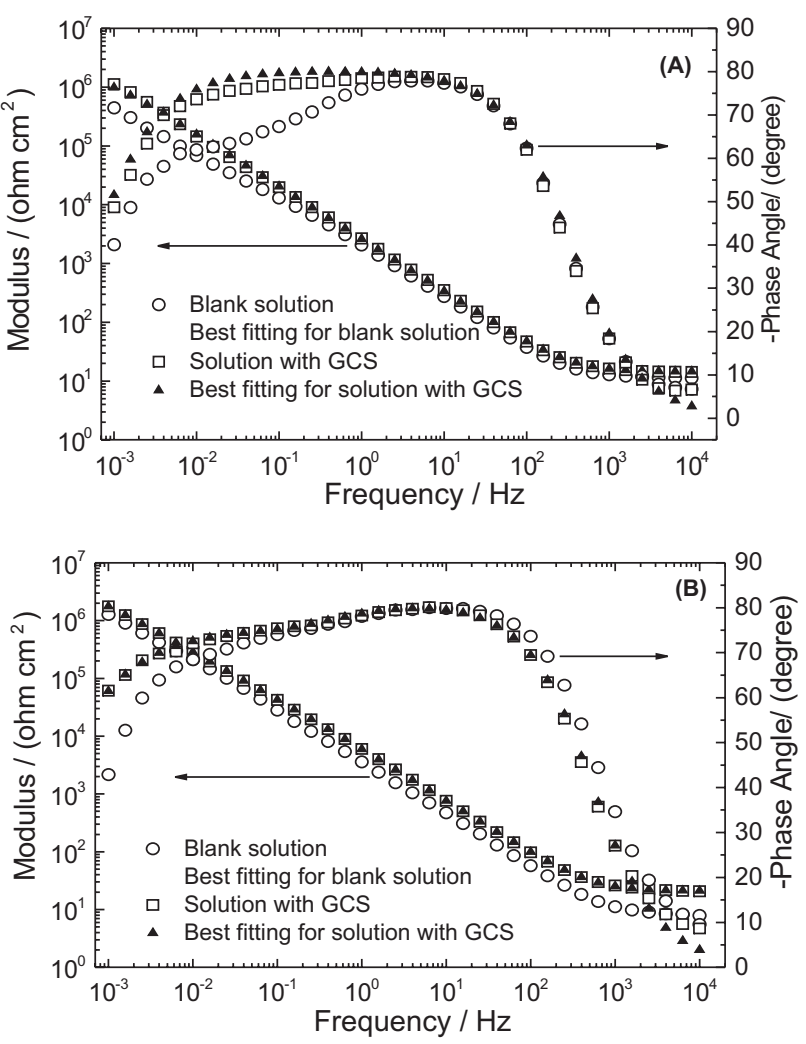

Figure 5. Bode diagrams obtained for carbon steel electrode at (A) 4 and (B) 8 days of immersion time in $\mathrm{NaOH} 0.1 \mathrm{~mol} \mathrm{~L}^{-1}$ solution and in the same solution contaminated with GCS.

due to series combination of double layer capacitance and the dielectric capacitance corresponding to this adsorbed layer. Nevertheless, if the double layer capacitance is about $100 \mu \mathrm{F} \mathrm{cm}^{-2}$ and the measured $\mathrm{C}_{1} 30 \mu \mathrm{F} \mathrm{cm}^{-2}$, the series capacitance shall be $40 \mu \mathrm{F} \mathrm{cm}^{-2}$, which gives film thickness about $10^{-10} \mathrm{~m}$, value not compatible with any physical film.

An alternative to explain the observed $\mathrm{C}_{1}$ decreasing is that GCS change the passive film's zero charge potential (ZCP) by modification of the outermost layer. The OCP shifts cathodically with time in presence of GCS and is globally more cathodic than in the blank solution. According to the literature concerning the electrochemical behaviour of steel in alkaline media, more cathodic potentials means more hydrated passive

Table 2. Best fitting parameters corresponding to data in Figure 5 using equation 1 as equivalent model

\begin{tabular}{|c|c|c|c|c|c|c|c|c|c|}
\hline & $\begin{array}{l}\text { Immersion } \\
\text { time / days }\end{array}$ & $\begin{array}{c}\mathrm{Re} / \\
\left(\Omega \mathrm{cm}^{2}\right)\end{array}$ & $\begin{array}{c}\mathrm{R}_{1} / \\
\left(\mathrm{k} \Omega \mathrm{cm}^{2}\right)\end{array}$ & $\begin{array}{c}\mathrm{C}_{1} / \\
\left(\mu \mathrm{F} \mathrm{cm}^{-2}\right)\end{array}$ & $\alpha_{1}$ & $\begin{array}{c}\mathrm{R}_{2} / \\
\left(\mathrm{k} \Omega \mathrm{cm}^{2}\right)\end{array}$ & $\begin{array}{c}\mathrm{C}_{2} / \\
\left(\mu \mathrm{F} \mathrm{cm}^{-2}\right)\end{array}$ & $\alpha_{2}$ & $\begin{array}{c}\mathrm{OCP} / \mathrm{mV} \\
(\mathrm{SCE})\end{array}$ \\
\hline $\mathrm{NaOH}$ & 4 & 11.5 & 28 & 100 & 0.9 & 500 & 188 & 0.7 & -176 \\
\hline $0.1 \mathrm{~mol} \mathrm{~L}^{-1}$ & 8 & 14.8 & 89 & 87 & 0.9 & 8800 & 55 & 0.7 & -148 \\
\hline \multicolumn{10}{|l|}{$\mathrm{NaOH}$} \\
\hline $0.1 \mathrm{~mol} \mathrm{~L}^{-1}$ & 4 & 19.7 & 260 & 32 & 0.9 & 8500 & 35 & 0.6 & -168 \\
\hline$+\mathrm{GCS}$ & 8 & 21.5 & 272 & 33 & 0.9 & 8900 & 55 & 0.7 & -190 \\
\hline
\end{tabular}


film, thus having different ZCP and higher resistance to corrosion by chlorides. ${ }^{10}$

\section{Solutions with chloride ions}

Cyclic potentiodynamic curves have also been recorded in the same alkaline solutions adding different chloride concentrations to reach to $0.2 \mathrm{~mol} \mathrm{~L}^{-1}$ and $0.5 \mathrm{~mol}$ $\mathrm{L}^{-1}$, thus nominal $\left[\mathrm{Cl}^{-}\right] /\left[\mathrm{OH}^{-}\right]$of 2 and 5 respectively. These $\left[\mathrm{Cl}^{-}\right] /\left[\mathrm{OH}^{-}\right]$ratios correspond to those necessary for rebar's depassivation at -200 and $-350 \mathrm{mV} v s$. SCE, respectively. ${ }^{11}$ In Figures 6 and 7, the obtained potentiodynamic curves are shown.

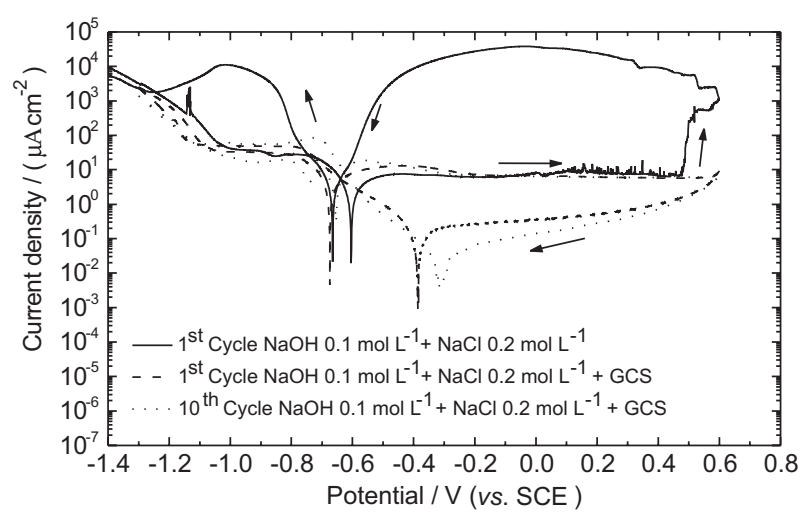

Figure 6. Potentiodynamic curve obtained for a carbon steel electrode in $\mathrm{NaOH} 0.1 \mathrm{~mol} \mathrm{~L}^{-1}+\mathrm{NaCl} 0.2 \mathrm{~mol} \mathrm{~L}^{-1}$ (with and without GCS) at $\mathrm{dE} / \mathrm{dt}=$ $1 \mathrm{mV} \mathrm{s}^{-1}$, from $-1.4 \mathrm{~V}$ to $+0.6 \mathrm{~V}$.

For carbon steel electrodes in chlorinated alkaline solutions, no matter the chloride concentration, the passive film breakdown occurs in the first forward scan, at about $+0.5 \mathrm{~V}$, although current transients typical of unstable pitting are observed since about $+0.1 \mathrm{~V}$. Nevertheless, pitting corrosion was not observed when the electrode is immersed in the suspensions containing GCS, which proves that the sludge protects carbon steel from pitting (at least during ten voltammetric cycles).

Electrochemical Impedance spectra were recorded on carbon steel in chlorinated $\left(0.5 \mathrm{~mol} \mathrm{~L}^{-1}\right)$ alkaline solution with and without slurries. Measurements were

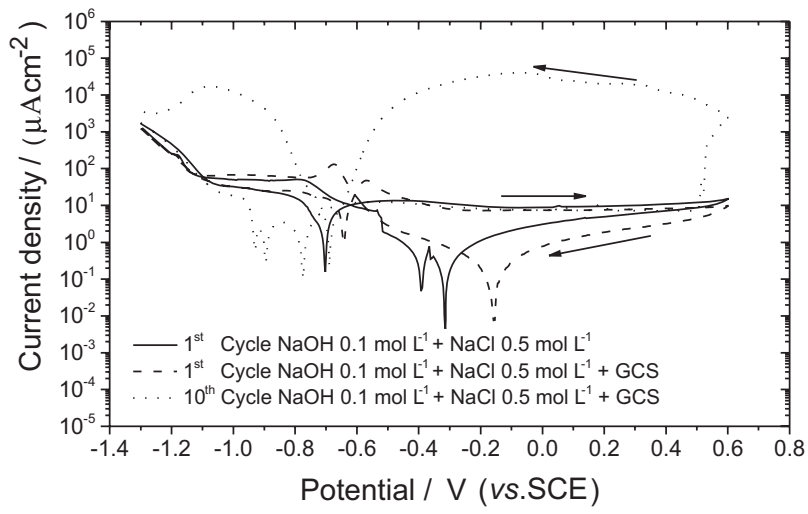

Figure 7. Potentiodynamic curves obtained for a carbon steel lectrode in $\mathrm{NaOH} 0.1 \mathrm{~mol} \mathrm{~L}^{-1}+\mathrm{NaCl} 0.5 \mathrm{~mol} \mathrm{~L}^{-1}$ (with and without GCS) at $\mathrm{dE} / \mathrm{dt}=$ $1 \mathrm{mV} \mathrm{s}^{-1}$, from $-1.4 \mathrm{~V}$ to $+0.6 \mathrm{~V}$.

performed at the corresponding $\mathrm{OCP}$, prior to pitting occurrence. All the obtained spectra present two well differentiated time constants, as shown in Figure 8, for 4 and 8 days immersion time. The experimental data were modelled using again equation 1 as impedance model. The best fitting parameters obtained for the data depicted in Figure 8 are given in Table 3. It can be seen that $R_{e}$ decreases (compared to values in Table 2) due to the higher ionic concentration in solutions containing chlorides; however, values for the solution containing GCS remain higher than those for the reference solution.

The $R_{1}$ values are much lower in Table 3 than in Table 2 which reveals activation of the corrosion process, which leads to thicker oxides layer. This result is consistent with $\mathrm{C}_{2}$ values, in the $\mathrm{mF} \mathrm{cm} \mathrm{cm}^{-2}$ range in presence of chlorides and $\mu \mathrm{F} \mathrm{cm}^{-2}$ without them.

The overall activation of the interface corresponds also to the $\mathrm{R}_{2}$ decreasing observed when values in Table 2 are compared with those in Table 3 . This $R_{2}$ decreasing corresponds to a change in the polarisation curve that can explain the potential shift from about $-190 \mathrm{mV}$ to $-350 \mathrm{mV}$ in presence of GCS; nevertheless the huge decrease from $-150 \mathrm{mV}$ to $-550 \mathrm{mV}$ observed

Table 3. Best fitting parameters corresponding to data in Figure 8 using equation 1 as equivalent model

\begin{tabular}{|c|c|c|c|c|c|c|c|c|c|}
\hline & $\begin{array}{l}\text { Immersion } \\
\text { time/ d }\end{array}$ & $\begin{array}{c}\mathrm{Re} / \\
\left(\Omega \mathrm{cm}^{2}\right)\end{array}$ & $\begin{array}{c}\mathrm{R}_{\mathrm{l}} / \\
\left(\mathrm{k} \Omega \mathrm{cm}^{2}\right)\end{array}$ & $\begin{array}{c}\mathrm{C}_{1} / \\
\left(\mu \mathrm{F} \mathrm{cm}^{-2}\right)\end{array}$ & $\alpha_{1}$ & $\begin{array}{c}\mathrm{R}_{2} / \\
\left(\mathrm{k} \Omega \mathrm{cm}^{2}\right)\end{array}$ & $\begin{array}{c}\mathrm{C}_{2} / \\
\left(\mathrm{mF} \mathrm{cm}^{-2}\right)\end{array}$ & $\alpha_{2}$ & $\begin{array}{c}\mathrm{OCP} / \mathrm{mV} \\
(\mathrm{SCE})\end{array}$ \\
\hline \multicolumn{10}{|l|}{$\mathrm{NaOH}$} \\
\hline $0.1 \mathrm{~mol} \mathrm{~L}^{-1}$ & 4 & 3.7 & 4.5 & 43 & 0.9 & 17 & 1.9 & 0.5 & -551 \\
\hline$+\mathrm{NaCl}$ & & & & & & & & & \\
\hline $0.5 \mathrm{~mol} \mathrm{~L}^{-1}$ & 8 & 3.7 & 12 & 53 & 0.9 & 18 & 8.8 & 0.4 & -552 \\
\hline $\mathrm{NaOH}$ & & & & & & & & & \\
\hline $0.1 \mathrm{~mol} \mathrm{~L}^{-1}$ & 4 & 5.1 & 16 & 27 & 0.9 & 50 & 1.4 & 0.5 & -365 \\
\hline$+\mathrm{NaCl}$ & & & & & & & & & \\
\hline $\begin{array}{l}0.5 \mathrm{~mol} \mathrm{~L}^{-1} \\
+\mathrm{GCS}\end{array}$ & 8 & 5.9 & 37 & 28 & 0.9 & 77 & 4.2 & 0.4 & -350 \\
\hline
\end{tabular}



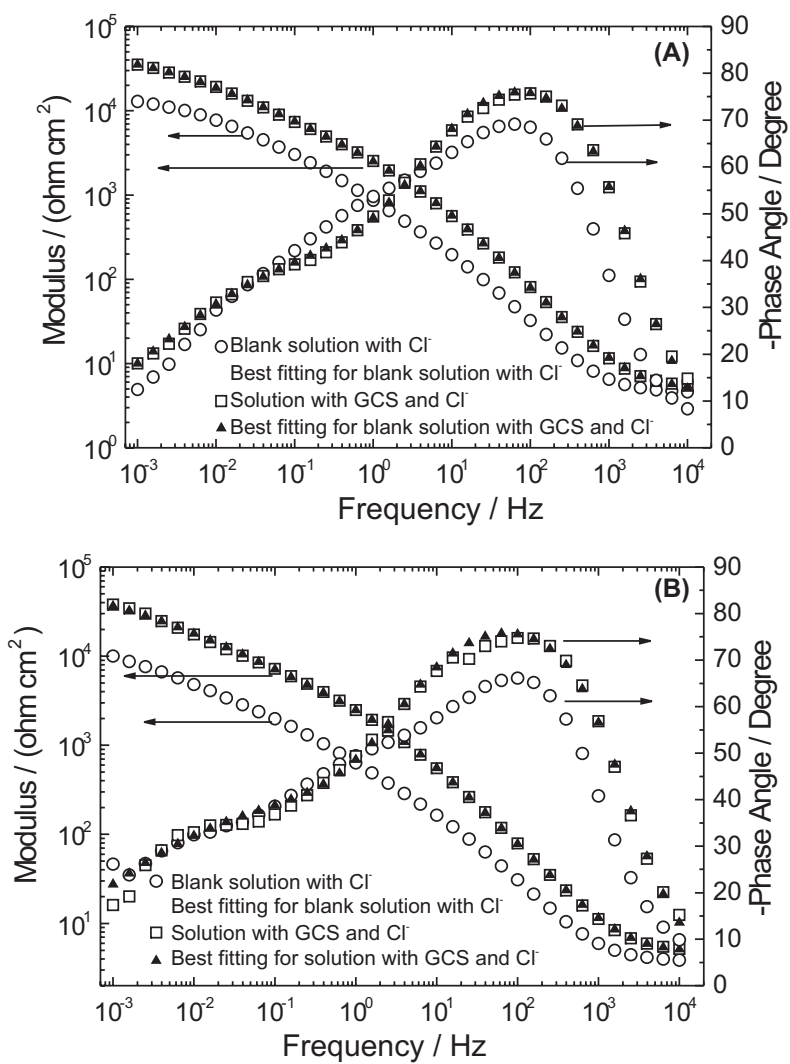

Figure 8. Bode diagrams obtained for carbon steel electrode at (A) 4 and (B) 8 days of immersion time in $\mathrm{NaOH} 0.1 \mathrm{~mol} \mathrm{~L}^{-1}+0.5 \mathrm{~mol} \mathrm{~L}^{-1} \mathrm{NaCl}$ solution with and without GCS.

in the reference solution can only be attributed to local loss of passivity with alternate cathodic reaction $\left(\mathrm{H}^{+} /\right.$ $\mathrm{H}_{2}$ instead of $\left.\mathrm{O}_{2} / \mathrm{OH}^{-}\right)$. In fact, pitting is visually observable after 10 days immersion in absence of GCS.

\section{Conclusions}

Small additions of Granite Cutting Slurries to alkaline solutions modify the natural passive layer formed on carbon steel. The peak current of the magnetite formation peak decreases in presence of GCS, indicating a corrosion rate reduction; moreover, the high frequency capacitance decreases, which has been attributed to modifications in the outermost level of the passive layer.

GCS are able to inhibit pitting of carbon steel in presence of chlorides. The steel remains passive after at least 10 voltammetric cycles while without GCS pitting occurs at the first cycle.

\section{Acknowledgment}

The authors wish to acknowledge the Spanish "Ministerio de Educación y Ciencia" for financial support under contract no. MAT2004-06435-C02-01.

\section{References}

1. Neville, A.M.; Properties of Concrete, Longman: Harlow, GB, 1995.

2. Sousa, J.; Cem. Concr. Compos. 2003, 25, 51.

3. Gonçalves, J.P.; Moura, W.A.; Coitinho Dal Molin, D.C.; Ambiente Construído 2002, 2, 53.

4. Andrade, C.; Merino, P.; Nóvoa, X. R.; Pérez, M. C.; Soler, L.; Mater. Sci. Forum 1995, 192-194, 891.

5. Moura, W.A.; Gonçalves, J.P.; Da Silva Leite, R.; Sitientibus 2002, 26, 49.

6. Díaz, B.; Joiret, S.; Keddam, M.; Nóvoa, X. R.; Pérez, M.C.; Takenouti, H.; Electrochim. Acta 2004, 49, 3039.

7. Joiret, S.; Keddam, M.; Nóvoa, X.R.; Pérez, M.C.; Rangel, C.; Takenouti, H.; Cem. Concr. Compos. 2002, 24, 7.

8. Andrade, C.; Keddam, M.; Nóvoa, X.R.; Pérez, M.C.; Rangel, C.M.; Takenouti, H.; Electrochim. Acta 2001, 46, 3905.

9. Abreu, C.M.; Cristóbal, M.J.; Montemor, M.F.; Nóvoa, X.R.; Pena, G.; Pérez, M.C.; Electrochim. Acta 2002, 47, 2271.

10. Collazo, A.; Cristóbal, M.J.; Nóvoa, X.R.; Pena, G.; Pérez, M.C.; J. ASTM International (JAI) 2006, 3, 2.

11. Alonso, C.; Castellote, M.; Andrade, C.; Electrochim. Acta 2002, 47, 3469.

Received: January 26, 2007

Web Release Date: September 12, 2007 